JOURNAL OF PUBLIC HEALTH INOVATION, VOL. 2 NO. 01, DESEMBER 2021

DOI: $10.34305 /$ jphi.v2i1.322
Ciptaan disebarluaskan di bawah Lisensi Creative Commons AtribusiNonKomersial-BerbagiSerupa 4.0

\title{
PENGARUH INTERVENSI HEALTH BELIEF MODEL DAN SEFT TERAPI \\ TERHADAP PERILAKU MEROKOK PADA KELOMPOK UPAYA KESEHATAN BERBASIS MASYARAKAT ROTUSU (ROKOK UNTUK SUSU DAN PROTEIN LAINNYA) DI KECAMATAN RANCAH 2020
}

Eni Desi Kaniawati, Laelatul Badriah, Lely Wahyuniar, Susianto, Ahmad Ropii

STIKes Kuningan

enidesi69@gmail.com

\begin{abstract}
Abstrak
Dalam beberapa kajian penyakit tidak menular seperti hipertensi, jantung, stroke, diabetes mellitus, Penyakit Paru Obstruktif Kronis (PPOK) dan lain-lain berhubungan erat dengan gaya hidup seperti diet tidak seimbang, kurang aktivitas fisik atau olah raga dan perilaku merokok. (UPTD Puskesmas Rancah kabupaten Ciamis, 2018) menunjukkan capaian rumah tangga ber PHBS di Kecamatan Rancah pada 2017 yaitu 35,88\%. Pada 2018 mengalami kenaikan yaitu 38,0\%. Dari 10 indikator PHBS rumah tangga capaian terendah adalah indikator tidak merokok di dalam rumah. UPTD Puskesmas Rancah melakukan tindak lanjut intervensi masalah rokok pada Program Indonesia Sehat dengan Pendekatan Keluarga dan pembinaan PHBS rumah tangga melalui kegiatan pembentukan UKBM (Upaya Kesehatan Berbasis Masyarakat) ROTUSU (Rokok Untuk Susu dan Protein Lainnya) sejak tahun 2019. UKBM ROTUSU adalah salah satu upaya inovatif yang dilatarbelakangi oleh tingginya perokok di Kecamatan Rancah juga karena masih rendahnya konsumsi protein hewani di keluarga. Tujuan penelitian ini untuk menganalisis pengaruh penerapan HBM dan SEFT Terapi terhadap perubahan perilaku merokok pada kelompok UKBM ROTUSU di Kec. Rancah 2020 . Jenis penelitian adalah quasi eksperimen dengan rancangan penelitian one group pre test and post test. Populasi adalah anggota kelompok UKBM ROTUSU 2020 sebanyak 130 orang.Pengambilan sampel dengan total sampling yaitu 130 orang. Sampel diberikan perlakuan baru yaitu pendekatan interpersonal dengan HBM dan SEFT Terapi. Sebelum dan sesudah perlakuan diukur perilaku merokok terkait jumlah yang dikonsumsi.

Analisis bivariat menghasilkan $\mathrm{p}$ value 0,000 pada penerapan intervensi HBM dan $\mathrm{p}$ value 0,000 pada penerapan intervensi SEFT Terapi terhadap perilaku merokok anggota kelompok UKBM ROTUSU di Kec. Rancah 2020.
\end{abstract}


JOURNAL OF PUBLIC HEALTH INOVATION, VOL. 2 NO. 01, DESEMBER 2021

DOI: $10.34305 /$ jphi.v2i1.322
Ciptaan disebarluaskan di bawah Lisensi Creative Commons AtribusiNonKomersial-BerbagiSerupa 4.0

Ada pengaruh intervensi HBM dan intervensi SEFT Terapi terhadap perilaku merokok pada kelompok UKBM ROTUSU di Kec. Rancah 2020. Intervensi SEFT Terapi terbukti lebih efektif dibandingkan dengan intervensi HBM.

Kata Kunci : Health Belief Model, SEFT Terapi, Perilaku Merokok, UKBM ROTUSU

\section{Pendahuluan}

Pola penyakit di Indonesia saat ini mengalami transisi epidemiologi yaitu pergeseran pola penyakit dari penyakit menular ke penyakit tidak menular. Dampak dari meningkatnya kasus penyakit tidak menular adalah meningkatnya pembiayaan pelayanan kesehatan yang harus ditanggung oleh masyarakat dan pemerintah, menurunnya produktivitas penduduk sehingga kesejahteraan masyarakat pun akan mengalami penurunan. Dalam beberapa kajian penyakit tidak menular seperti hipertensi, jantung, stroke, diabetes mellitus, Penyakit Paru Obstruktif Kronis (PPOK) dan lain-lain berhubungan erat dengan gaya hidup seperti diet tidak seimbang, kurang aktivitas fisik atau olah raga dan perilaku merokok.

Laporan terbaru dari World Health Organization (WHO) yang dirilis pada akhir 2019 (lifestyle.com, 3 September 2020) menyebut bahwa selama hampir dua dekade terakhir, keseluruhan penggunaan tembakau (rokok, cerutu, rokok kretek) global telah mengalami penurunan. Pada 2010 angka yang tercatat adalah 1,397 miliar orang di seluruh dunia sementara pada 2018 angkanya berkurang menjadi 1,337 miliar. Artinya dalam hampir 20 tahun terakhir, jumlah pengguna tembakau atau merokok telah turun sekitar 60 juta orang di dunia. Namun meskipun terjadi penurunan, angka prevalensi perokok masih sangat tinggi dan menimbulkan dampak buruk..

Data Riset Kesehatan Dasar (Riskesdas, 2018) dengan populasi seluruh rumah tangga di Indonesia, menggunakan metode Probability Proportional to Size menggunakan Linear Systematic Sampling dengan Two Stage Sampling menunjukkan prevalensi merokok setiap hari dan kadangkadang pada penduduk umur $\geq 10$ tahun yaitu 28,8\%. Provinsi Jawa Barat menempati urutan tertinggi pertama yaitu $32,0 \%$. Prevalensi merokok pada penduduk umur 10-18 tahun pada tahun 2018 yaitu 9,1\%. Hal ini mengalami kenaikan dari Riskesdas (2013) yaitu 2\%. Laporan 
JOURNAL OF PUBLIC HEALTH INOVATION, VOL. 2 NO. 01, DESEMBER 2021

DOI: $\underline{10.34305 / \text { jphi.v2i1.322 }}$

Kinerja Instansi Pemerintah, Dinkes Jabar (2016) menyampaikan capaian rumah tangga ber PHBS (Perilaku Hidup Bersih Sehat) pada 2016 di provinsi Jawa Barat yaitu 52,5\% sedangkan tahun 2017 naik menjadi $57,80 \%$ dimana dari 10 indikator PHBS, indikator tidak merokok di dalam rumah merupakan indikator dengan capaian terendah.

(UPTD Puskesmas Rancah kabupaten Ciamis, 2018) menunjukkan capaian rumah tangga berPHBS di Kecamatan Rancah pada 2017 yaitu 35,88\%. Pada 2018 mengalami kenaikan yaitu 38,0\%. Dari 10 indikator PHBS rumah tangga capaian terendah adalah indikator tidak merokok di dalam rumah. Selain itu hasil pendataan PIS-PK tahun 2018 dengan sistem total coverage diperoleh kesimpulan bahwa Kecamatan Rancah memiliki Indeks Keluarga Sehat (IKS) 0,304 sehingga diartikan sebagai Kecamatan tidak sehat. Dari 12 indikator keluarga sehat indikator yang capaiannya terendah yaitu indikator anggota keluarga tidak ada yang merokok yaitu 35,5\%, sedangkan 10 indikator lainnya berkisar $39,1 \%$ - 99\%. Artinya bahwa angka perokok masih sangat tinggi di kalangan masyarakat Kecamatan Rancah.
Ciptaan disebarluaskan di bawah Lisensi Creative Commons AtribusiNonKomersial-BerbagiSerupa 4.0 Internasional.

Adiksi rokok berkaitan dengan masalah psikis, maka berhenti merokok juga berkaitan dengan keadaan psikologis seseorang. Menurut (Baradja F, 2013) apabila seorang pecandu rokok ingin berhenti merokok maka keinginan menjadi syarat utamanya. Keinginan yang kuat akan memudahkan proses berhenti merokok. Menumbuhkan keinginan memerlukan motivasi yang kuat dan harus diawali dengan pemberian informasi yang akurat dan meyakinkan. Health Belief Model (HBM) merupakan salah satu pendekatan interpersonal yang bertujuan membuat individu menerapkan perilaku preventif terhadap suatu permasalahan kesehatan. Tiga faktor penting dalam HBM yaitu kesiapan individu untuk merubah perilaku, dorongan dalam lingkungan yang membuatnya merubah perilaku dan perilaku itu sendiri (Fatmawati S, 2019). Titik beratnya adalah pembentukan persepsipersepsi tentang permasalahan kesehatan tersebut. Untuk membentuk persepsipersepsi tersebut individu harus diberikan pengetahuan praktis tentang suatu permasalahan kesehatan.

\section{Spiritual Emotional Freedom} Technique (SEFT) yaitu terapi untuk membantu menyelesaikan atau menyembuhkan berbagai masalah 
JOURNAL OF PUBLIC HEALTH INOVATION, VOL. 2 NO. 01, DESEMBER 2021

DOI: $10.34305 /$ jphi.v2i1.322

kesehatan baik fisik maupun psikis. Perilaku merokok sendiri merupakan suatu permasalahan psikis yaitu individu merasakan ketergantungan terhadap zat zat yang terkandung dalam rokok khususnya nikotin. Ketergantungan tersebut berkaitan dengan rasa senang, tenang atau rileks. Perokok yang tidak mendapat asupan nikotin akan merasakan kegelisahan, kesulitan konsentrasi dan kesulitan tidur. (Munawaroh, 2017) mengatakan SEFT Terapi banyak digunakan untuk mengatasi ketergantungan terhadap merokok. SEFT Terapi dapat menjadi media terapi untuk berhenti dari perilaku merokok, dengan ketentuan bagi klien sebelumnya telah memiliki niat (kemauan) agar sembuh dari perilaku tersebut.

\section{UPTD Puskesmas Rancah}

melakukan tindak lanjut intervensi masalah rokok pada Program Indonesia Sehat dengan Pendekatan Keluarga dan pembinaan PHBS rumah tangga melalui kegiatan pembentukan UKBM (Upaya Kesehatan Berbasis Masyarakat) ROTUSU (Rokok Untuk Susu dan Protein Lainnya) sejak tahun 2019. UKBM ROTUSU adalah salah satu upaya inovatif yang dilatarbelakangi oleh tingginya perokok di Kecamatan Rancah juga karena masih rendahnya konsumsi protein hewani di
Ciptaan disebarluaskan di bawah Lisensi Creative Commons AtribusiNonKomersial-BerbagiSerupa 4.0 Internasional.

keluarga. Di setiap desa terdapat 1 kelompok UKBM ROTUSU yang masingmasing kelompok beranggotakan 5 pasang suami istri dengan kriteria ada perokok, memiliki bayi atau balita, keluarga miskin, diutamakan peserta BPJS PBI (penerima bantuan iuran) (Petunjuk Teknis Pembinaan UKBM ROTUSU, 2019).

Untuk mengevaluasi efektivitas intervensi yang paling sesuai dengan sasaran UKBM ROTUSU maka harus dilakukan penelitian agar diperoleh faktafakta yang berguna untuk dijadikan bahan kajian perencanaan kegiatan intervensi perubahan perilaku merokok di Kecamatan Rancah. Penentuan model intervensi yang efektif akan menjadi kunci keberhasilan program sehingga efektifitas sumber daya dapat dioptimalkan. Pemberian intervensi dengan model yang tepat diharapkan dapat menurunkan prevalensi perokok sehingga kesehatan dan kesejahteraan masyarakat dapat meningkat.

\section{Metode}

Jenis penelitian adalah quasi eksperimen dengan sampel diberikan perlakuan baru yaitu pendekatan interpersonal dengan HBM dan SEFT Terapi. Sebelum dan sesudah perlakuan diukur perilaku merokok terkait jumlah yang dikonsumsi. Desain penelitian 
JOURNAL OF PUBLIC HEALTH INOVATION, VOL. 2 NO. 01, DESEMBER 2021

DOI: $\underline{10.34305 / \text { jphi.v2i1.322 }}$

yaitu one group pre test and post test study design. Populasi penelitian yaitu seluruh perokok di wilayah kerja UPTD Puskesmas Rancah yang menjadi anggota UKBM ROTUSU 2020 sebanyak 130 orang.

Sampel yang diambil adalah dengan cara total sampling yaitu 130 orang perokok anggota UKBM ROTUSU 2020 yang dibagi menjadi 2 kelompok yaitu 65 sampel dengan intervensi $\mathrm{HBM}$ dan 65 sampel dengan intervensi SEFT Terapi. Namun setelah melalui pentahapan intervensi sebanyak 12 kali, terdapat 1 sampel kelompok HBM yang tidak dapat meneruskan intervensi karena pindah pekerjaan ke luar kota dan sampel dengan
Ciptaan disebarluaskan di bawah Lisensi Creative Commons AtribusiNonKomersial-BerbagiSerupa 4.0 Internasional. intervensi SEFT Terapi ada 6 orang yang tidak dapat menyelesaikan 12 kali intervensi dengan berbagai alasan sehingga dilakukan drop out. Sampel yang digunakan untuk intervensi HBM sebanyak 64 orang dan untuk SEFT Terapi 59 orang.

Peneliti mengambil data primer secara langsung terhadap sampel penelitian. Melakukan wawancara terpimpin terhadap sampel dan observasi saat dilakukan SEFT Terapi. Sedangkan untuk pengumpulan data sekunder dilakukan sebelum dilakukan pengambilan data primer. Analisis data menggunakan uji Wilcoxon sebagai uji beda 2 kelompok berpasangan dan uji Mann-Whitney.

\section{Hasil}

Tabel 1.1 Gambaran Karakteristik Anggota Kelompok UKBM ROTUSU di Kecamatan Rancah 2020 dengan Intervensi HBM

\begin{tabular}{|c|c|c|}
\hline Karakteristik & n & $\%$ \\
\hline \multicolumn{3}{|l|}{ Kelompok Umur } \\
\hline$\leq 30$ th & 13 & 20,3 \\
\hline $31-40$ th & 24 & 37,5 \\
\hline $41-50$ th & 27 & 42,2 \\
\hline$>50$ th & 0 & 0 \\
\hline Total & 64 & 100 \\
\hline \multicolumn{3}{|l|}{ Pendidikan } \\
\hline Belum tamat SD & 1 & 1,6 \\
\hline SD/Sederajat & 26 & 40,6 \\
\hline SMP/Sederajat & 27 & 42,2 \\
\hline SMA/Sederajat & 10 & 15,6 \\
\hline Perguruan Tinggi & 0 & 0 \\
\hline Total & 64 & 100 \\
\hline \multicolumn{3}{|l|}{ Pekerjaan } \\
\hline Buruh Harian Lepas & 20 & 31,3 \\
\hline Wiraswasta & 24 & 37,5 \\
\hline Karyawan Swasta & 0 & 0 \\
\hline Pedagang & 1 & 1,6 \\
\hline Petani/Buruh tani & 8 & 12,5 \\
\hline Lainnya & 11 & 17,2 \\
\hline Total & 64 & 100 \\
\hline
\end{tabular}

Sumber : Data Primer 2021 
JOURNAL OF PUBLIC HEALTH INOVATION, VOL. 2 NO. 01, DESEMBER 2021

DOI: $\underline{10.34305 / \text { jphi.v2i1.322 }}$
Ciptaan disebarluaskan di bawah Lisensi Creative Commons AtribusiNonKomersial-BerbagiSerupa 4.0 Internasional.
Dari tabel 1.1 dapat disimpulkan bahwa dari 64 sampel umur anggota kelompok UKBM ROTUSU yang diberikan intervensi HBM terbanyak ada pada kelompok umur 41-50 tahun sebanyak 27 orang atau $42,2 \%$, kelompok umur yang terendah atau $0 \%$ yaitu diatas 50 tahun. Pendidikan pada anggota kelompok UKBM ROTUSU yang diberikan intervensi HBM terbanyak ada pada kelompok pendidikan SD 26 orang atau $40,6 \%$ dan paling sedikit pendidikan belum tamat SD yaitu 1 orang atau $1,6 \%$. Pekerjaan pada anggota kelompok UKBM ROTUSU yang diberikan intervensi HBM terbanyak adalah wiraswasta sebanyak 24 orang atau $37,5 \%$ dan paling sedikit dengan pekerjaan pedagang yaitu 1 orang atau $1,6 \%$.

Tabel 1.2 Gambaran Karakteristik Anggota Kelompok UKBM ROTUSU di Kecamatan Rancah 2020 dengan Intervensi SEFT Terapi

\begin{tabular}{lcc}
\hline \multicolumn{1}{c}{ Karakteristik } & $\mathbf{n}$ & $\mathbf{\%}$ \\
\hline Kelompok Umur & 4 & 6,8 \\
$\leq 30$ th & 30 & 50,8 \\
$31-40$ th & 20 & 33,9 \\
$41-50$ th & 5 & 8,5 \\
$>50$ th & $\mathbf{5 9}$ & $\mathbf{1 0 0}$ \\
\hline Total & 1 & 1,7 \\
\hline Pendidikan & 13 & 22,0 \\
Belum tamat SD & 34 & 57,6 \\
SD/Sederajat & 9 & 15,3 \\
SMP/Sederajat & 2 & 3,4 \\
SMA/Sederajat & $\mathbf{5 9}$ & $\mathbf{1 0 0}$ \\
Perguruan Tinggi & & \\
\hline Total & 12 & 20,3 \\
\hline Pekerjaan & 31 & 52,5 \\
Buruh Harian Lepas & 4 & 6,8 \\
Wiraswasta & 3 & 5,1 \\
Karyawan Swasta & 4 & 6,8 \\
Pedagang & 5 & 8,5 \\
Petani/Buruh tani & $\mathbf{5 9}$ & $\mathbf{1 0 0}$ \\
Lainnya & & \\
\hline Total & & \\
\hline Sumber : Data Primer 2021 & &
\end{tabular}

Dari tabel 1.2 dapat disimpulkan bahwa dari 59 sampel umur anggota kelompok UKBM ROTUSU yang diberikan intervensi SEFT Terapi terbanyak yaitu kelompok umur 31-40 tahun yaitu 30 orang atau $50,8 \%$, dan terendah yaitu kelompok umur kurang dari sama dengan 30 tahun sebanyak 4 orang atau $6,8 \%$. 
JOURNAL OF PUBLIC HEALTH INOVATION, VOL. 2 NO. 01, DESEMBER 2021

DOI: $\underline{10.34305 / \text { jphi.v2i1.322 }}$

Pendidikan pada anggota kelompok UKBM ROTUSU yang diberikan intervensi SEFT terapi terbanyak adalah pendidikan SMP 34 orang atau $57,6 \%$ dan paling sedikit pendidikan belum tamat SD yaitu 1 orang atau $1,7 \%$. Pekerjaan pada anggota
Ciptaan disebarluaskan di bawah Lisensi Creative Commons AtribusiNonKomersial-BerbagiSerupa 4.0 Internasional. kelompok UKBM ROTUSU yang diberikan intervensi SEFT Terapi terbanyak adalah wiraswasta sebanyak 32 orang atau $52,5 \%$ dan paling sedikit dengan pekerjaan pedagang yaitu 3 orang atau 5,1\%.

Tabel 1.3 Distribusi Frekuensi Perilaku Merokok Sebelum dan Sesudah Intervensi Anggota Kelompok UKBM ROTUSU di Kecamatan Rancah 2020 dengan Intervensi HBM

\begin{tabular}{lcccc}
\hline \multirow{2}{*}{ Karakteristik } & \multicolumn{2}{c}{ Pre Test } & \multicolumn{2}{c}{ Post Test } \\
\cline { 2 - 5 } & n & \% & n & \% \\
\hline Jumlah Konsumsi Rokok & & & & \\
0 batang & 0 & 0 & 18 & 28,1 \\
$<6$ batang & 5 & 7,8 & 1 & 1,6 \\
6-12 batang & 38 & 59,4 & 25 & 39,1 \\
$>12$ batang & 21 & 32,8 & 20 & 31,3 \\
\hline Jenis Rokok & & & & \\
Tidak Merokok & 0 & 0 & 18 & 28,1 \\
Filter & 17 & 26,0 & 16 & 25,0 \\
Kretek & 47 & 73,4 & 30 & 46,9 \\
\hline Merokok di dalam Rumah & & & & \\
Ya & 46 & 71,9 & 26 & 40,6 \\
Tidak & 18 & 28,1 & 38 & 59,4 \\
\hline Merokok Saat Bekerja & & & & \\
Ya & 56 & 87,5 & 41 & 64,1 \\
Tidak & 8 & 12,5 & 23 & 35,9 \\
\hline
\end{tabular}

Sumber: Data Primer 2021

Dari tabel 1.3 dapat disimpulkan bahwa anggota kelompok UKBM ROTUSU yang diberikan intervensi HBM pada awal intervensi jumlah konsumsi rokok rata-rata per hari tertinggi yaitu 6-12 batang sebanyak 38 sampel atau 59,4\%. Setelah intervensi jumlah konsumsi rokok rata-rata per hari tertinggi masih 6-12 batang namun terjadi penurunan frekuensi menjadi 25 sampel atau 39,1\%. Jenis rokok yang dikonsumsi pada awal intervensi tertinggi yaitu jenis kretek sebanyak 47 sampel atau $73,4 \%$. Setelah intervensi jenis rokok yang dikonsumsi tertinggi masih jenis kretek namun terjadi penurunan frekuensi menjadi 30 sampel atau 46,9\%. Perilaku merokok di dalam rumah sebelum diberikan intervensi sebanyak 46 sampel 
JOURNAL OF PUBLIC HEALTH INOVATION, VOL. 2 NO. 01, DESEMBER 2021

DOI: $\underline{10.34305 / \text { jphi.v2i1.322 }}$

atau $71,9 \%$ sedangkan setelah diberikan intervensi turun menjadi 26 sampel atau 40,6\%. Perilaku merokok saat bekerja sebelum diberikan intervensi sebanyak 56
Ciptaan disebarluaskan di bawah Lisensi Creative Commons AtribusiNonKomersial-BerbagiSerupa 4.0 Internasional.

sampel atau $87,5 \%$ sedangkan setelah intervensi turun menjadi 41 sampel atau $64,1 \%$.

Tabel 1.4 Distribusi Frekuensi Perilaku Merokok Sebelum dan Sesudah Intervensi Anggota Kelompok UKBM ROTUSU di Kecamatan Rancah 2020 dengan Intervensi SEFT Terapi

\begin{tabular}{|c|c|c|c|c|}
\hline \multirow{2}{*}{ Karakteristik } & \multicolumn{2}{|c|}{ Pre Test } & \multicolumn{2}{|c|}{ Post Test } \\
\hline & $\mathbf{n}$ & $\%$ & $\mathbf{n}$ & $\%$ \\
\hline \multicolumn{5}{|l|}{ Jumlah Konsumsi Rokok } \\
\hline 0 batang & 0 & 0 & 15 & 25,4 \\
\hline$<6$ batang & 4 & 6,8 & 25 & 42,4 \\
\hline 6-12 batang & 45 & 76,3 & 16 & 27,1 \\
\hline$>12$ batang & 10 & 16,9 & 3 & 5,1 \\
\hline \multicolumn{5}{|l|}{ Jenis Rokok } \\
\hline Tidak Merokok & 0 & 0 & 15 & 25,4 \\
\hline Filter & 22 & 37,3 & 14 & 23,7 \\
\hline Kretek & 37 & 62,7 & 30 & 50,8 \\
\hline \multicolumn{5}{|l|}{ Merokok di dalam Rumah } \\
\hline $\mathrm{Ya}$ & 45 & 76,3 & 1 & 1,7 \\
\hline Tidak & 14 & 23,7 & 58 & 98,3 \\
\hline \multicolumn{5}{|l|}{ Merokok Saat Bekerja } \\
\hline $\mathrm{Ya}$ & 53 & 89,9 & 20 & 33,9 \\
\hline Tidak & 6 & 10,2 & 39 & 66,1 \\
\hline
\end{tabular}

Sumber: Data Primer 2021

Dari tabel 1.4 dapat disimpulkan bahwa anggota kelompok UKBM ROTUSU yang diberikan intervensi SEFT Terapi pada awal intervensi jumlah konsumsi rokok rata-rata per hari tertinggi yaitu 6-12 batang sebanyak 45 sampel atau $76,3 \%$. Setelah intervensi jumlah konsumsi rokok rata-rata per hari tertinggi yaitu $<6$ batang sebanyak 25 sampel atau $42,2 \%$. Jenis rokok yang dikonsumsi pada awal intervensi tertinggi yaitu jenis kretek sebanyak 37 sampel atau $62,7 \%$. Setelah intervensi jenis rokok yang dikonsumsi tertinggi masih jenis kretek namun terjadi penurunan frekuensi menjadi 30 sampel atau 50,8\%. Perilaku merokok di dalam rumah sebelum diberikan intervensi sebanyak 45 sampel atau 76,3\% sedangkan setelah diberikan intervensi turun menjadi 1 sampel atau 1,7\%. Perilaku merokok saat bekerja sebelum diberikan intervensi sebanyak 53 sampel atau 89,9\% sedangkan setelah intervensi turun menjadi 20 sampel atau $33,9 \%$. 
JOURNAL OF PUBLIC HEALTH INOVATION, VOL. 2 NO. 01, DESEMBER 2021

DOI: $10.34305 /$ jphi.v2i1.322
Ciptaan disebarluaskan di bawah Lisensi Creative Commons AtribusiNonKomersial-BerbagiSerupa 4.0 Internasional

Tabel 1.5 Persepsi Awal dan Akhir Anggota Kelompok UKBM ROTUSU di Kecamatan Rancah 2020 dengan Intervensi HBM

\begin{tabular}{lcccc}
\hline \multirow{2}{*}{ Ketegori Persepsi } & \multicolumn{2}{c}{ Pre Test } & \multicolumn{2}{c}{ Post Test } \\
\cline { 2 - 5 } & $\mathbf{n}$ & $\mathbf{\%}$ & $\mathbf{n}$ & $\mathbf{\%}$ \\
\hline Lemah & 13 & 20,3 & 2 & 3,1 \\
Sedang & 47 & 73,4 & 33 & 51,6 \\
Kuat & 4 & 6,3 & 29 & 45,3 \\
Total & $\mathbf{6 4}$ & $\mathbf{1 0 0}$ & $\mathbf{6 4}$ & $\mathbf{1 0 0}$ \\
\hline Sumber: Data Primer 2021 & & &
\end{tabular}

Dari tabel 1.5 dapat disimpulkan bahwa sebelum diberikan intervensi HBM, persepsi kuat terhadap perilaku merokok hanya 4 sampel atau $6,3 \%$ sedangkan setelah diberikan intervensi HBM, persepsi kuat bertambah menjadi 29 orang atau 45,3\%. Persepsi lemah pada sebelum diberikan intervensi sebanyak 13 sampel atau $20,3 \%$ dan setelah diberikan intervensi turun menjadi 2 sampel atau 3,1\%.

Tabel 1.6 Gambaran SEFT Terapi Awal dan Akhir Anggota Kelompok UKBM ROTUSU di Kecamatan Rancah 2020 dengan Intervensi SEFT Terapi

\begin{tabular}{lcccc}
\hline \multirow{2}{*}{ Kategori SEFT Terapi } & \multicolumn{2}{c}{ Pre Test } & \multicolumn{3}{c}{ Post Test } \\
\cline { 2 - 5 } & $\mathbf{n}$ & $\mathbf{\%}$ & $\mathbf{n}$ & $\mathbf{\%}$ \\
\hline Berhasil & 28 & 47,5 & 53 & 89,8 \\
Tidak Berhasil & 31 & 52,5 & 6 & 10,2 \\
Total & $\mathbf{5 9}$ & $\mathbf{1 0 0}$ & $\mathbf{5 9}$ & $\mathbf{1 0 0}$ \\
\hline
\end{tabular}

Sumber: Data Primer 2021

Dari tabel 1.6 dapat disimpulkan bahwa pada awal dilakukan intervensi SEFT Terapi sampel yang ada pada kelompok tidak berhasil sebanyak 31 sampel atau 52,\%. Namun pada intervensi yang ke 12 kali sampel yang tidak berhasil terdapat penurunan menjadi 6 sampel atau $10,2 \%$.

Tabel 1.7 Uji Beda Perilaku Merokok pada Anggota Kelompok UKBM ROTUSU di Kecamatan Rancah 2020 Sebelum dan Sesudah Intervensi HBM

\begin{tabular}{lccc}
\hline \multicolumn{1}{c}{ Perilaku merokok } & Mean (batang) & P Value & Keputusan \\
\hline Pretest & 16 & 0,000 & Hipotesis diterima \\
Posttest & 6 & &
\end{tabular}


JOURNAL OF PUBLIC HEALTH INOVATION, VOL. 2 NO. 01, DESEMBER 2021

DOI: $10.34305 /$ jphi.v2i1.322

Berdasarkan Tabel 1.7 di atas dapat diketahui bahwa nilai signifikansi sebesar $0,000<$ taraf signifikansi 0,05, maka hipotesis pertama pada penelitian ini diterima. Artinya bahwa terdapat perbedaan yang signifikan antara perilaku merokok sebelum dengan sesudah dilakukan intervensi HBM. Sebelum diberikan
Ciptaan disebarluaskan di bawah Lisensi Creative Commons AtribusiNonKomersial-BerbagiSerupa 4.0 Internasional.

Tabel 1.8 Uji Beda Perilaku Merokok pada Anggota Kelompok UKBM ROTUSU di Kecamatan Rancah 2020 Sebelum dan Sesudah Intervensi SEFT Terapi

\begin{tabular}{lccc}
\hline \multicolumn{1}{c}{ Perilaku merokok } & Mean (batang) & P Value & Keputusan \\
\hline Pretest & 14 & 0,000 & Hipotesis diterima \\
Posttest & 4 & & \\
\hline
\end{tabular}
Sumber: Data Primer 2021

Berdasarkan Tabel 1.8 dapat diketahui bahwa nilai signifikansi sebesar $0,000<$ taraf signifikansi 0,05, maka hipotesis kedua pada penelitian ini diterima. Artinya bahwa terdapat perbedaan yang signifikan antara perilaku merokok sebelum dengan sesudah dilakukan intervensi SEFT Terapi. Sebelum diberikan intervensi SEFT intervensi HBM rata-rata sampel merokok dengan sebanyak 16 batang, sedangkan setelah dilakukan intervensi HBM menurun rata-rata menjadi 6 batang. Dengan demikian dapat disimpulkan bahwa intervensi HBM memberikan pengaruh yang signifikan dalam menurunkan perilaku merokok

sampel.

Terapi rata-rata sampel merokok dengan
sebanyak 14 batang, sedangkan setelah
dilakukan intervensi SEFT Terapi menurun
rata-rata menjadi 4 batang. Dengan
demikian dapat disimpulkan bahwa
intervensi SEFT Terapi memberikan
pengaruh yang signifikan dalam
menurunkan perilaku merokok sampe

Tabel 1.9 Uji beda perilaku merokok sesudah dilakukan intervensi HBM dan SEFT Terapi

\begin{tabular}{|c|c|c|c|}
\hline Intervensi & Mean(batang) & P Value & Keputusan \\
\hline HBM & 6 & 0,027 & Hipotesis Ditolak \\
\hline SEFT & 4 & & \\
\hline
\end{tabular}

Sumber: Data Primer 2021 
JOURNAL OF PUBLIC HEALTH INOVATION, VOL. 2 NO. 01, DESEMBER 2021

DOI: $\underline{10.34305 / \text { jphi.v2i1.322 }}$

Berdasarkan Tabel 1.9 dapat diketahui bahwa nilai signifikansi sebesar $0,027<$ taraf signifikansi 0,05 , artinya bahwa terdapat perbedaan yang signifikan antara perilaku merokok sesudah dilakukan intervensi HBM dengan SEFT Terapi. Rata-rata jumlah batang rokok yang dihisap oleh sampel setelah dilakukan intervensi HBM adalah 6 batang, sedangkan rata-rata jumlah batang rokok yang dihisap oleh sampel setelah dilakukan intervensi SEFT Terapi adalah 4 batang. Pada hipotesis diduga bahwa intervensi HBM lebih efektif dibandingkan dengan intervensi SEFT
Ciptaan disebarluaskan di bawah Lisensi Creative Commons AtribusiNonKomersial-BerbagiSerupa 4.0 Internasional.

Terapi namun dari hasil uji dapat disimpulkan bahwa intervensi SEFT Terapi memberikan pengaruh yang lebih efektif dalam menurunkan perilaku merokok sampel, dibandingkan intervensi HBM artinya hipotesis ditolak.

Uji BNT atau LSD digunakan untuk mengetahui perbedaan rata-rata perlakuan paling sederhana, sehingga dapat mengetahui perlakuan mana yang paling efektif dibandingkan lainnya. Berikut hasil analisis uji BNT pada penelitian ini adalah sebagai

berikut:

Tabel 1.10 Uji BNT perilaku merokok sesudah dilakukan intervensi HBM dan SEFT Terapi

\begin{tabular}{lccc}
\hline \multicolumn{1}{c}{ Intervensi } & N & Mean & Notes \\
\hline HBM & 70 & 5,529 & $\mathrm{~A}^{*}$ \\
SEFT Terapi & 53 & 3,566 & $\mathrm{~B}^{*}$ \\
\hline
\end{tabular}

Sumber : Data Olahan 2021

Berdasarkan hasil analisis uji BNT di atas dapat diketahui bahwa intervensi HBM dan SEFT Terapi memiliki perbedaan yang signifikan, yang mana SEFT Terapi merupakan intervensi yang lebih efektif dibandingkan HBM dalam menurunkan perilaku merokok sampel, yang ditandai dengan rata-rata konsumsi rokok responden dengan intervensi SEFT Terapi lebih rendah yaitu 3,5 batang, sedangkan rata-rata konsumsi rokok sampel dengan intervensi HBM sebanyak 5,5 batang.

\section{Pembahasan}

1. Pengaruh Intervensi HBM Terhadap Perilaku Merokok pada Anggota Kelompok UKBM ROTUSU di Kecamatan Rancah 2020

Dalam penelitian diketahui bahwa intervensi HBM yang dilakukan pada 64 sampel dapat mempengaruhi perilaku 
JOURNAL OF PUBLIC HEALTH INOVATION, VOL. 2 NO. 01, DESEMBER 2021

DOI: $\underline{10.34305 / \text { jphi.v2i1.322 }}$

merokok. Sebelum diberikan intervensi HBM rata-rata sampel merokok 16 batang per hari dan setelah diberikan intervensi HBM menurun menjadi rata-rata 6 batang perhari. Hal ini sejalan dengan penelitian (Khazaee Dkk, 2016) yang menyatakan bahwa penerapan HBM efektif terhadap perilaku pencegahan merokok di kalangan siswa sekolah menengah. Penelitian sejenis juga dilakukan oleh (Kazemi Dkk, 2012) yang membuktikan bahwa pendidikan HBM pada ibu hamil merupakan cara yang efektif untuk menurunkan pajanan asap rokok walaupun tidak cukup untuk membuat rumah menjadi bebas asap rokok. (Panahi dkk, 2017) juga menyatakan HBM merupakan prediktor penerapan perilaku pencegahan merokok.

Kondisi kecanduan rokok merupakan gabungan antara masalah fisik dan psikis. (PramudiyaAD, 2015) menyebutkan bahwa adiksi merupakan suatu kondisi ketergantungan fisik dan mental terhadap hal-hal tertentu yang menimbulkan perubahan perilaku bagi orang yang mengalaminya. Dopamin adalah salah satu neurotransmitter pada sistem saraf yang mengatur aliran darah dalam pembuluh darah, kebiasaaan makan, proses belajar dan kognitif, perilaku, aktivitas motorik, perasaan, proses motivasi dan
Ciptaan disebarluaskan di bawah Lisensi Creative Commons AtribusiNonKomersial-BerbagiSerupa 4.0 Internasional.

imbalan. Dopamin yang ada dalam mesolimbik paling penting untuk proses motivasi. Beberapa zat dapat meningkatkan aktivitas dopamin mesolimbik seperti nikotin yang terkandung dalam rokok. Adiksi terhadap nikotin ini timbul akibat paparan berulang dimana dopamine akan dilepaskan secara abnormal. Menurut (ASA, 2016) adiksi merupakan sebuah fenomena kompleks yang melibatkan sejumlah besar faktor mulai dari tingkat molekuler sampai ke tingkat interaksi sosial. Hal tersebut juga terjadi pada adiksi nikotin atau rokok dimana seorang perokok akan mengalami masalah di otak, psikologis (mental) dan juga sosial. Di dalam struktur otak terdapat pula fungsi eksekutif. (Pasiak dkk, 2019) menyebutkan salah satu fungsi eksekutif otak adalah kontrol inhibisi yang berfungsi menahan godaan dan mengontrol perilaku agar tidak bertindak impulsif.

Dalam intervensi HBM sampel mendapatkan penjelasan sehingga terbentuk persepsi bahwa rokok dapat menyebabkan timbulnya berbagai penyakit. Selain itu sampel diberikan penjelasan dampak dari penyakit-penyakit baik bagi kondisi tubuh maupun pengobatan dan pemeliharaan yang dibutuhkan. Walaupun sebagian besar responden adalah peserta JKN PBI namun 
JOURNAL OF PUBLIC HEALTH INOVATION, VOL. 2 NO. 01, DESEMBER 2021

DOI: $10.34305 /$ iphi.v2i1.322

tetap disampaikan beban pengobatan untuk berbagai penyakit diatas sehingga sampel memiliki persepsi tentang mahalnya penyakit-penyakit tersebut. Manfaat perubahan perilaku meliputi manfaat jika merokok tidak dilakukan di dalam rumah sehingga sebagian besar responden mengalihkan tempat merokoknya menjadi di luar rumah. Manfaat lain yaitu untuk kebugaran dan kesehatan tubuh, menjaga stabilitas ekonomi keluarga dan lain-lain. Hambatan dalam perubahan perilaku merokok banyak dirasakan oleh para perokok dalam proses perubahan perilakunya. Dalam intervensi ini dijelaskan hambatan-hambatan tersebut sehingga responden memahami dan dapat mempersiapkan diri jika hambatan tersebut muncul dalam proses perubahan perilaku merokoknya.

Pada saat sampel diberikan penjelasan informasi bahaya rokok, tubuhnya akan memberi respon yang baru terhadap rokok. Beberapa sampel mengungkapkan kekhawatiran, ketakutan dan niat untuk merubah perilaku merokok. Dari reaksi itu dapat disimpulkan bahwa persepsi yang terbentuk akan merubah sistem kerja otak dimana secara fisiologis otak yang berfungsi sebagai kontrol inhibisi akan memberi sinyal untuk menahan
Ciptaan disebarluaskan di bawah Lisensi Creative Commons AtribusiNonKomersial-BerbagiSerupa 4.0 Internasional.

godaan dan mengontrol perilaku merokoknya. Pada intervensi HBM ditekankan tentang bahaya rokok terhadap anak-anak yang akan terpapar jika merokok dilakukan di dalam rumah. Dari hal tersebut perubahan pertama dalam perilaku merokok sampel adalah perpindahan tempat merokok yang semula dilakukan di dalam rumah menjadi di luar rumah.

Persepsi-persepsi yang dibentuk dalam 12 kali intervensi termasuk unsur psikologis yang akan meningkatkan fungsi eksekutif otak yaitu kontrol inhibisi. sampel akan merasa bertanggung jawab terhadap kesehatan keluarga, merasa sedih jika anggota keluarga khususnya anak-anak menjadi sakit atau mengalami hambatan tumbuh kembang akibat rokok. Pada saat intervensi berlangsung beberapa sampel mengalami penyesalan dengan ekspresi menangis. Pada saat tersebut, control inhibisi terjadi dengan ditandai adanya pengendalian perilaku. Dapat disimpulkan bahwa persepsi yang dibentuk mempengaruhi psikologis maupun fisiologis dalam otak dan sistem saraf sehingga proses perubahan perilaku merokok dapat terjadi mulai dari perpindahan tempat merokok menjadi di luar rumah, mengurangi frekuensi merokok dan berhenti merokok. 
JOURNAL OF PUBLIC HEALTH INOVATION, VOL. 2 NO. 01, DESEMBER 2021

DOI: $10.34305 /$ iphi.v2i1.322

2. Pengaruh Intervensi SEFT Terapi Terhadap Perilaku Merokok pada Anggota Kelompok UKBM ROTUSU di Kecamatan Rancah 2020

Dalam penelitian diketahui bahwa intervensi SEFT Terapi yang dilakukan pada 59 sampel dapat mempengaruhi perilaku merokok. Sebelum diberikan intervensi SEFT Terapi rata-rata sampel merokok 14 batang per hari dan setelah diberikan intervensi SEFT Terapi menurun menjadi rata-rata 4 batang perhari. Menurut (CF, 2016) SEFT Terapi efektif terhadap penurunan intensitas merokok yang dilakukan penelitiannya pada Klinik Berhenti Merokok UPTD Puskesmas Kecamatan Pontianak Kota. Hal ini disebabkan SEFT Terapi dapat merelaksasi seseorang dan membebaskan seseorang dari berbagai tekanan emosional. Merokok merupakan salah satu aktivitas yang bisa dilakukan untuk mengurangi beban emosional seperti stres karena di dalam rokok terkandung zat nikotin yang merangsang pengeluaran hormon dopamine, endorphin dan serotonin yang membuat seseorang menjadi nyaman, senang dan tenang. (Aminuddin dkk, n.d.) dalam laporan Pengabdian Masyarakat nya menyimpulkan bahwa SEFT Terapi pada masyarakat dapat mengubah persepsi
Ciptaan disebarluaskan di bawah Lisensi Creative Commons AtribusiNonKomersial-BerbagiSerupa 4.0 Internasional.

masyarakat tentang rokok dimana yang semula merokok membuat nyaman dan tenang menjadi terasa pahit dan merasa mual setelah memperoleh SEFT Terapi. Hal ini dapat menurunkan intensitas merokok pada masyarakat.

(MA, 2016) menyebutkan bahwa nyeri kronis dan stres diketahui merupakan faktor resiko dalam kerentanan akan terjadinya adiksi. Pada awal seseorang menghisap rokok terdapat beberapa kemungkinan penyebabnya seperti pengaruh pergaulan, coba-coba dan untuk menekan stres. Terlepas dari penyebab awal perilaku merokok, setelah terjadi paparan berulang nikotin, stres dan jenuh menjadi alasan perokok menginginkan asupan nikotin sehingga dopamine terangsang untuk keluar dan menyebabkan rasa tenang dan senang. Pada pecandu rokok situasi tanpa stresor pun akan dirasakan sebagai stres karena kondisi otaknya yang telah mengalami perubahan akibat adiksi sehingga meskipun keadaan kehidupan baik-baik saja perokok tetap membutuhkan nikotin untuk ketenangan dan kesenangannya.

Intervensi SEFT Terapi yang diberikan terhadap 59 sampel dalam penelitian ini dilakukan selama 12 kali dengan interval satu minggu. Dapat 
JOURNAL OF PUBLIC HEALTH INOVATION, VOL. 2 NO. 01, DESEMBER 2021

DOI: $\underline{10.34305 / \text { jphi.v2i1.322 }}$

disimpulkan bahwa SEFT Terapi dapat membangkitkan sisi spiritual seseorang dimulai dari pengucapan doa dan kepasrahan dengan penekanan di area jantung untuk menambah kekhusuan karena sampel dapat merasakan sakit tekan dan detak jantungnya sendiri sehingga responden akan berada di titik terendah di hadapan Tuhannya. Tapping atau penotokan di titik-titik meridian tubuh mengembalikan energi positif sehingga sampel yang melakukannya dengan khusyu akan mendapatkan energi positif, tubuh menjadi rileks, otak kembali ke dalam kondisi yang normal sehingga merasakan ketidaknyamanan saat merokok dan ketidakmampuan menghisap rokok.

3. Intervensi yang Paling Efektif untuk Merubah Perilaku Merokok

Hasil perhitungan analisis menyatakan bahwa intervensi SEFT Terapi lebih efektif dibandingkan dengan intervensi HBM. SEFT Terapi jika dilakukan dengan motivasi yang kuat dan kekhusukan maka pengaruhnya akan dapat dirasakan langsung oleh sampel. Diantara pengaruh yang dapat mempengaruhi perilaku merokok adalah rasa dari rokok yang berubah menjadi hambar, pahit, mual, muntah, batuk dan perasaan tercekik. Sedangkan pada sampel yang diberikan
Ciptaan disebarluaskan di bawah Lisensi Creative Commons AtribusiNonKomersial-BerbagiSerupa 4.0 Internasional.

intervensi HBM rasa rokok yang dihisap tidak ada perubahan. Perubahan perilaku merokok benar-benar berdasarkan persepsi yang dibentuk dari intervensi. Bagi sampel yang terbentuk persepsi kuat maka akan terjadi perubahan perilaku merokok bahkan sampai berhenti merokok.

Sisi spiritual pada kelompok intervensi SEFT Terapi dibangkitkan lebih sering yaitu setiap kali intervensi. Hal ini memperdalam kualitas spiritual sampel sehingga sampel akan lebih tenang secara psikologis dan kerja otaknya menjadi lebih normal. Masalah-masalah pada otak terkait adiksinya mulai diperbaiki sehingga sampel tidak membutuhkan pengeluaran dopamine secara abnormal untuk mendapatkan perasaan senang dan bahagia. Pada kelompok HBM sisi spiritual tidak ditekankan di setiap sesi intervensi. Sehingga kemungkinan sisi spiritual sampel dengan intervensi HBM tidak sedalam dan sefokus kelompok intervensi SEFT Terapi.

Sampel kelompok intervensi SEFT Terapi yang mendapatkan sentuhan langsung oleh SEFTer cenderung lebih fokus sehingga sampel lebih mudah menerima stimulus melalui indra-indranya. Pengaruhnya secara fisiologis pada otak lebih cepat dibandingkan dengan sampel pada intervensi HBM. Ketukan pada 
JOURNAL OF PUBLIC HEALTH INOVATION, VOL. 2 NO. 01, DESEMBER 2021

DOI: $\underline{10.34305 / \text { jphi.v2i1.322 }}$

intervensi SEFT Terapi juga membantu membuka saluran energi sehingga sampel akan merasa lebih berenergi positif, bugar dan bahagia. Kelompok intervensi HBM hanya mengandalkan stimulasi indra pendengaran dan penglihatan yang membentuk persepsi-persepsi baru sehingga memerlukan upaya yang lebih keras agar tubuhnya khususnya otak kembali pada sistem yang normal. Pada intervensi HBM juga ada kemungkinan pembentukan persepsi dalam kelompok tidak terbentuk secara seragam. Pengetahuan awal, pendidikan, daya serap (kognitif), fokus dan konsentrasi menjadi hal mendasar dimana pembentukan persepsi terjadi.

\section{Kesimpulan}

1. Ada pengaruh intervensi HBM terhadap perilaku merokok pada kelompok UKBM ROTUSU di Kec. Rancah 2020.

2. Ada pengaruh intervensi SEFT Terapi terhadap perilaku merokok pada kelompok UKBM ROTUSU di Kec. Rancah 2020.

3. Ada perbedaan pengaruh intervensi HBM dan SEFT Terapi terhadap perilaku merokok pada kelompok UKBM ROTUSU di Kec. Rancah 2020 dengan nilai signifikansi 0,027 dimana SEFT Terapi lebih efektif dibandingkan
Ciptaan disebarluaskan di bawah Lisensi Creative Commons AtribusiNonKomersial-BerbagiSerupa 4.0 Internasional.

dengan HBM dalam mempengaruhi perilaku merokok pada kelompok UKBM ROTUSU di Kec. Rancah 2020.

\section{Daftar Pustaka}

Aminuddin dkk, M. (n.d.). Terapi Seft Menurunkan Intensitas Kebiasaan Merokok di Kelurahan Sambutan Kota Samarinda. Jurnal Pengabdian Dan Pemberdayaan Masyarakat.

ASA, S. (2016). Ketergantungan Nikotin; Aspek Molekuler dan Implikasi Terapi Berbasis Bukti. Continuing Medical Education, 43(4), 267-273.

Baradja F. (2013). Hari Gini Masih Merokok,apa Kata Dunia?!/. Pro-U Media.

CF, B. (2016). Efektifitas Terafi Seft (Spiritual Emotional Freedom Technique) terhadap Penurunan Intensitas Merokok di Klinik Berhenti Merokok UPTD Puskesmas Kecamatan Pontianak Kota. Jurnal Proners.

Dkk, Kazemi. (2012). A Randomized Trial to Promote Health Belief and to Reduce Environmental Tobacco Smoke Exposure in Pregnant Women. Health Education Research, 012(27), 151-159.

Dkk, Khazaee. (2016). The Effect Of An Educational Intervention Based On Health Belief Model On Improving Smoking Preventive Behaviors. Iranian Journal of Health Education \& Promotion, 4.

Fatmawati S. (2019). The implementation of Spiritual Emotional Freedom 
JOURNAL OF PUBLIC HEALTH INOVATION, VOL. 2 NO. 01, DESEMBER 2021

DOI: $\underline{10.34305 / \text { jphi.v2i1.322 }}$
Ciptaan disebarluaskan di bawah Lisensi Creative Commons AtribusiNonKomersial-BerbagiSerupa 4.0 Internasional.

Technique (S-EFT) to Reduce Selfdiscomfort A Study among College Students. SCITEPRESS-Science and Technology

Publications.Lda.2019:130-146.

MA, T. (2016). Pengaruh Stres dan nyeri terhadap Resiko Adiksi Morfin pada Hewan Coba Mencit (Mus Musculus). Universitas Airlangga Repository.

Munawaroh, S. (2017). Terafi Spiritual Emotional Freedom technique (SEFT) untuk Menangani Perilaku Kecanduan Merokok di Komunitas Sefter Solo. Repositori IAIN Surakarta.

Panahi dkk, R. (2017). Panahi R, dkk Predictors of Adoption of Smoking Preventive Behaviors among University Students: Application of Health Belief Model. Journal of Education and Commnunity Health, 4, J. Educ. Commnunity Heal.

Pasiak dkk, M. (2019). Gambaran Kinerja Otak Mahasiswa Fakultas Kedokteran UNSRAT dengan Adiksi Nikotin Menggunakan Instrumen ISHA. . 2019.Vol 1 no $3: 1-5$. Jurnal Medik Dan Rehabilitasi (JMR), 1(3), 1-5.

PramudiyaAD. (2015). Landasan konseptual Perencanaan dan Perancangan Panti Rehabilitasi Narkoba di Yogyakarta.

Riskesdas. (2018). Kementrian Kesehatan Republik Indonesia.

UPTD Puskesmas Rancah kabupaten Ciamis. (2018). Profil Puskesmas Rancah Tahun 2017. 